\title{
Phytoindication of environmental mutagenesis in the in-situ conditions using the pollen of selected species of native flora
}

\author{
Karol Mičieta \\ Comenius University, Faculty of Natural Sciences, Department of Botany, Révová 39, 81102 \\ Bratislava, Slovakia, karol.micieta@uniba.sk
}

Mičieta K. (2021): Phytoindication of environmental mutagenesis in the in-situ conditions using the pollen of selected species of native flora. Thaiszia - J. Bot. 31 (1): 069-078.

\begin{abstract}
The aim of this study is to provide an effective method for indicating ecogenotoxicity in the environment using pollen grains and microspores of selected species of the native flora in the in situ conditions. In the report, we summarize the results of long-term experience with the benefits of native flora species as bioindicators of polluted environments. We present the current results of long-term monitoring of phytoindication of ecogenotoxicity in Bratislava and selected traffic junctions in Slovakia. The increase of pollen grain abortion in the group of localities exposed to a heavy load of traffic pollution demonstrates the ecogenotoxic impact of traffic emissions in the environment. The detailed practical methodological tools and possible difficulties with the classification of abortivity of microspores and pollen grains of these plant species are discussed.
\end{abstract}

Keywords: pollen abortivity, environmental pollution, ecogenotoxicity, native flora, phytoindication.

\section{Introduction}

Contamination has become inherent to the modern environment. The global and rapid increase in technogenic stress in the biosphere raises the question about possible consequences for biota, including man - when we acknowledge that all forms of life are interconnected and that human health is strongly linked to the 
ecosystem's health. Therefore, a clear understanding of all the dangers posed by environmental pollutants to human health and ecologic systems is needed. Knowledge of the existence of an environmental stress situation is the prerequisite for its solution or amelioration. In this respect, considerable efforts have been made to develop effective methods for assessing environmental health.

The rapid increase in industrialization is alarming regarding the survival of living creatures and is damaging the ecological balance (Iqbal et al. 2019). Continued release of untreated industrial wastes/leachates to the rivers contaminates the entire ecosystem (Bianchi et al. 2011; Salles et al. 2016). The continuous exposure of organisms to dangerous chemical substances may cause chromosomal abnormalities that can cause diseases and affect the human offspring (Leme \& Marin-Morales 2009; Mazzeo et al. 2018).

Higher plants are a complex integrator of interacting processes and generally meet all the conditions for bioindication. Their advantages are, in particular:they have a natural integrating function in dynamic media; live directly in the environment or where standardized model test systems are implanted; are easily identifiable; give a general or specific response to a change in the environment; do not escape from the polluted environment (respectively can be cultivated as needed); allow to monitor the genotoxic effect of a risk factor or several risk factors, the effect of residues or their metabolites (Mičieta \& Murín 1996, 2018).

Higher plants have already shown their ability to fulfil all requisite conditions for the bioindication of genotoxicity of environmental chemicals (cf. De Serres 1978; Constantin \& Owens 1982). Nevertheless, nearly all methods were "in vivo" tests (cf. Grant 1982; Grant \& Zura 1982; Grant et al. 1992; Vig 1982; Ma 1982, 1999; Van't Hof \& Schairer 1982; Plewa 1982; Murín (1984).

There is no doubt that in this field they could hardly compete with the routine methods of testing mutagens and/or carcinogens using bacterial and mammalian material. On the other hand, plant tests are cheaper, and approximately $60-70 \%$ of hazardous chemicals have the same effects in plant tests as in bacterial and mammalian tests (cf. Constantin \& Owens 1982; Grant 1982; Grant et al. 1992; Ma 1982b). An international effort was finally focused within the WHO/IPCS collaborative study to standardize certificated tests of the genotoxic effects of xenobiotics for practical use in laboratories with basic equipment and standard cultivating conditions (Kanaya et al. 1994). The outcome of this project was four short-term bioassays (Allium, Vicia, Arabidopsis, and Tradescantia) for rapid screening of chemicals for clastogenicity and mutagenicity (Ma 1999). Plant test models such as Allium cepa, Vicia faba, Tradescantia, Pisum sativum, Hordeum vulgare, Zea mays, Crepis capillaris, Nicotiana tabacum are currently in common use as a favourable and efficient genetic model under "in vivo" conditions to test in particular the toxicity of contaminated environmental components (cf. Bhat et al. 2017, 2019; Mazzeo et al. 2018; Iqbal et al. 2019).

Many studies have developed numerous methods for the detection of mutagenicity and genotoxicity in "in vivo" conditions based on the accepted plant 
tests in WHO / IPCS, which are currently commonly used in the Arabidopsis thaliana, Allium / Vicia chromosome aberration test, Tradescantia stamen hair mutation and micronucleus analysis, Sister chromatid exchange, Fluorescent in situ hybridization, Terminal deoxynucleotidyl transferase dUTP nick end labeling (TUNEL assay), Singlecell gel electrophoresis (comet assay), Random amplified polymorphic DNA polymerase chain reaction (RAPD-PCR) technique, Real-time polymerase chain reaction (RT-PCR) technique, Flow cytometry (cf. Aksoy 2017)

The use of plants as models for tests of environmental ecotoxicity and ecogenotoxicity was reported by, e.g., Paradiž \& Lovka (1999), Pogányová et al. (2017, 2019), Mičieta \& Murín (2018).

\section{Material and Methods}

The broad spectra of plant species allow utilizing all levels of sensitive genetic material of plants to detect environmental pollution. These are pollen grains/microspores, micronuclei in tetrads, and chromosomal aberrations/mitotic abnormalities in meiosis and mitosis.

To indicate the phytotoxicity and ecogenotoxicity in the exposed locality, we take samples of pollen and microspores of indicator species of the local flora, or cultivated plants in field culture. The plant material fixation is realized according to the published procedures (Mičieta \& Murín 1996, 1997, 2007).

Significant enrichment of the method for long-term or retrospective monitoring was elaborating of the procedure for the use of herbarium items by Mičieta \& Murín (1999).

The sampling, preparation of slides for each type of evaluation, and evaluation of abortions of the pollen grains, micronuclei in tetrads, chromosomal aberrations, and mitotic or meiotic abnormalities is presented in Mičieta \& Murín (1989, 1997, 2007, 2018).

The basic criteria for using pollen grains as markers of the polluted environment were described by Murín (1987), Mičieta (1989) and later completed by Murín (1995). They are:

1. The selected species must be diploid (with haploid pollen grains) to avoid high pollen abortion, which is common in polyploids.

2. The plants should produce well-developed and viable pollen grains under common climatic conditions (pollen abortion less than 5\%).

3. The plants should have a common distribution and also grow in urban and industrial habitats.

4. Blooming seasons of various plant species should be in a sequence to cover the whole vegetation period.

5. The identification of selected plant species in question should be easy and indubitable for common practice.

6. It is advisable to select both terrestrial and aquatic plant species.

7. It is advantageous to choose (if possible) plant species with persistent pollen tetrads for easy distinction of physiological and genetic damage to the pollen grains. 
We validated the presented method at localities with significant xenobiotic exposure of the urban environment, especially at traffic junctions, in localities: Bratislava - Šafárikovo town square, Bratislava, Botanical garden of the Comenius University (reference control locality for Taxus baccata), Bratislava - Istrochem, Banská Bystrica - city district Kostiviarska, Žiar nad Hronom - Partizánska street, Považská Bystrica - centre and Žilina - city district Budatín (Fig. 1 and Fig. 2).

Abortivity of pollen grains from the study sites was compared to an unpolluted control locality (reference site) in a protected landscape area of the Záhorie region, approx. $2 \mathrm{~km}$ from the Závod village (GPS: $48^{\circ} 31^{\prime} 21.18^{\prime \prime} \mathrm{N}, 17^{\circ} 3^{\prime} 30.23^{\prime \prime} \mathrm{E}$ ).

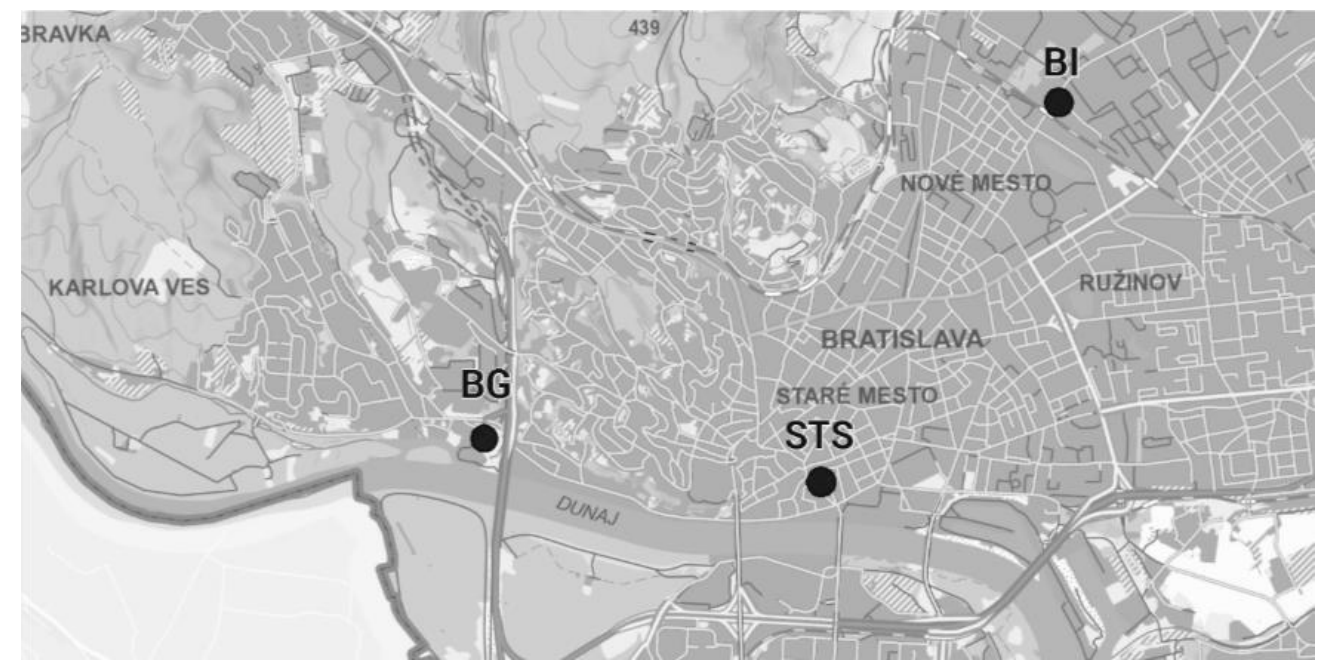

Fig. 1 Monitored sites in area of the city of Bratislava, Slovakia, Europe: BG - Botanical garden of the Comenius University, STS - Šafárikovo town square, BI - Istrochem (chemical plant).

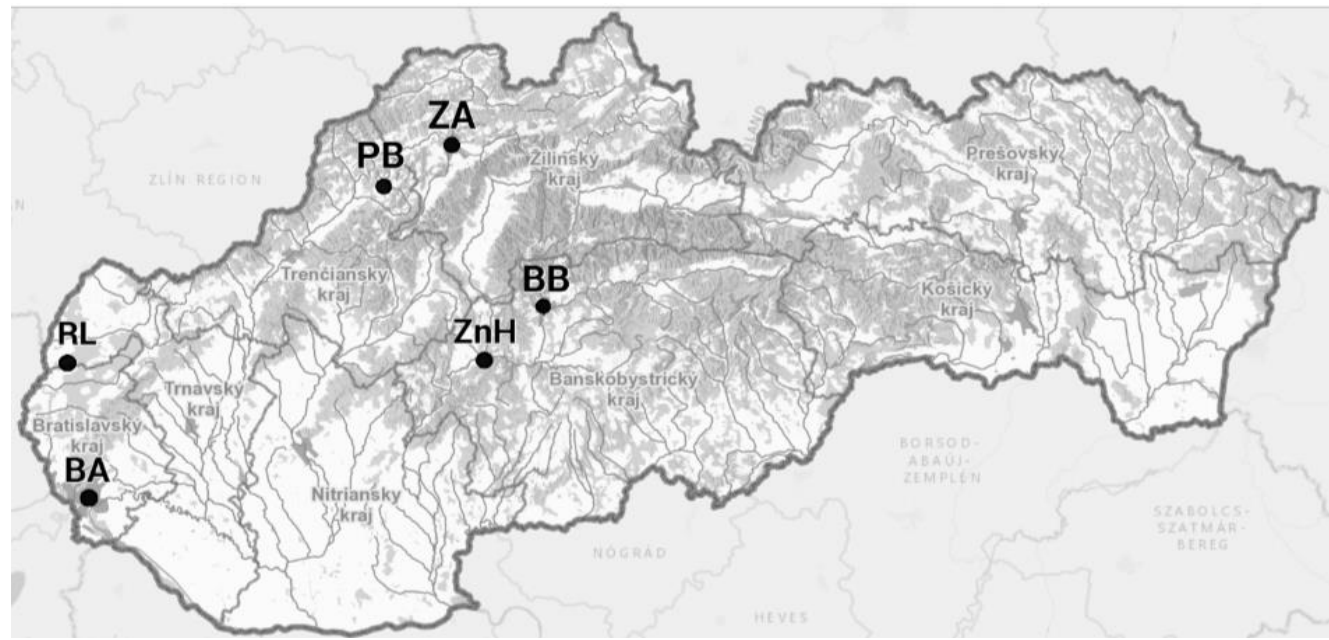

Fig. 2 Monitored sites in area of Slovakia, Europe. BA - Bratislava city, RL - reference (control) locality Závod village, $\mathrm{PB}$ - Považská Bystrica - city centre, ZA - Žilina, city district Budatín, BB - Banská Bystrica, city district Kostiviarska, ZnH - Žiar nad Hronom - Partizánska street 
The statistical analysis between samples from a control locality and the study sites is recommended to be conducted following the procedure of Amphlett \& Delow (1984), which is based on the Poisson distribution. The analysis of variance (ANOVA) and Wilcoxin sign-rank (one sided) test are also useful for the data. All assessments must be made under blind conditions.

For an indication of ecogenotoxicity in selected species of local flora and the subsequent determination of the induction index and increase of ecogenotoxicity in a specific locality, we recommend implementing the published procedure of Mičieta \& Kunová (2000); Mišík et al. (2007) with the mathematical formula: idx (induction index) = sts (pollen abortivity at the study site)/ rfs (pollen abortivity at the reference site). A detected value of the induction index of more than 1.0 represents significantly increased pollen abortivity compared to the reference control site.

\section{Results and discussion}

Besides the implantation of standardized indicator models (Tradescantia, Zea), pollen grains, mother pollen cells, and pollen tetrads of the selected diploid species of the native local flora and crop plants species used as a basic bioindicative material have been significantly applied in the detection of ecogenotoxicity in the in situ conditions (Mičieta \& Murín 1996, 1997, 2018).

The advantage of this material is its high sensitivity, which is conditioned by the haploid state, and the quantity required for the corresponding statistical analysis of the results. The use of microspores and pollen makes it possible to effectively detect parallel damage at all three structural levels of the genetic apparatus of the cell; the impact of short-term and long-term exposure; impacts of an acute and persistent environmental load as well as adaptation mechanisms, individual and population response in different types of environmental load (Mičieta \& Murín 1996, 2007, 2018; Solenská et al. 2006; Mišík et al. 2009; Pogányová et al. 2017, 2019).

The plant species standardly used for practical tests of the polluted environment were mostly specially cultivated species, only partially useful in field conditions. Therefore, our laboratory was specialized in preparing the tests using wild and cultivated plants as bioindicators. A starting point for this effort was the report of Murín (1987). The method is efficient and easily applicable. It represents a simple and economical procedure suitable for long-term observations, giving a database also usable in sudden environmental pollution incidents. We believe that plant species are the best bioindicators "in situ" as they live directly in the corresponding polluted environment, and this makes it possible to evaluate a real set of ecological factors and components of pollution.

The efficiency, operability, and provability of the pollen grain abortion in the indication of ecogenotoxicity are presented on the long-term monitoring results of the indicator species Taxus baccata made from 1998 to 2020 (Fig. 3) on the Šafárikovo town square in Bratislava. The locality was extremely exposed to urban traffic emissions until 2011. It is compared with the reference locality at the Botanical Garden of Comenius University in Bratislava. The exclusion of traffic and 
reconstruction of the tram line is the cause of a demonstrable reduction in the frequency of pollen abortivity. In 2020, it was lower than at the reference site, which is increasingly exposed by traffic on the Lafranconi Bridge. Induction index (Mičieta, Kunová 2000; Mišík et al. 2007) was used for the basic comparison of data from different sites. We compared the pollen abortivity of a minimum of ten studies at each different polluted site to evaluate the effect of pollution on plant species reaction. These species mostly belonged to synanthropic flora for their widespread occurrence in chosen areas. The impact of traffic emissions, currently a significant source of xenobiotic exposure in the urban environment, is presented at traffic junctions in localities Banská Bystrica, Kostiviarska, Žiar nad Hronom (Partizánska street), Považská Bystrica centre, Žilina - Budatín and Bratislava Istrochem in 2009, 2011, 2013, 2015, 2017 and 2018 (Fig. 4). The increase of average induction indexes at the studied localities clearly demonstrates the xenobiotic exposure influence, especially traffic emissions, on genotoxic deterioration of genetic material.

The use of herbarium items in retrospective monitoring of genotoxicity according to the procedure of Mičieta \& Murín (1999) is presented on the partial results from the city centre of Bratislava in the years 1866 to 2018 (Fig. 5). Induction indexes, for example, from 1960,1978, 1983, are low due to an insufficiently large group; the study is a current process. However, it can be stated that since 1940, the pollution of the environment of Bratislava has increased twice $(1962,1963)$ compared to the reference locality Záhorská nížina lowland. The results show that emissions from local sources and the chemical industry are currently replacing traffic emissions.

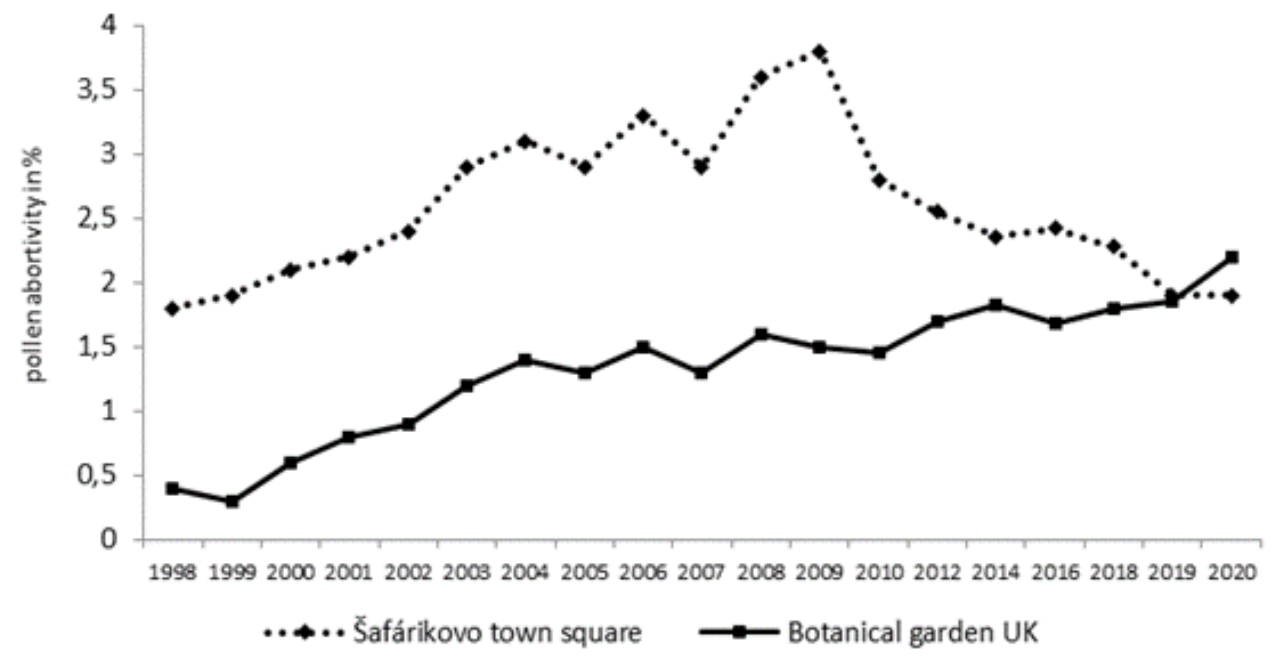

Fig. 3 Pollen abortivity of Taxus baccata in the urban area of Bratislava. (The locality Šafárikovo town square, until 2011 extremely exposed by urban traffic emissions, is compared with the reference control locality the Botanical Garden of Comenius University for Taxus baccata in Bratislava.) 


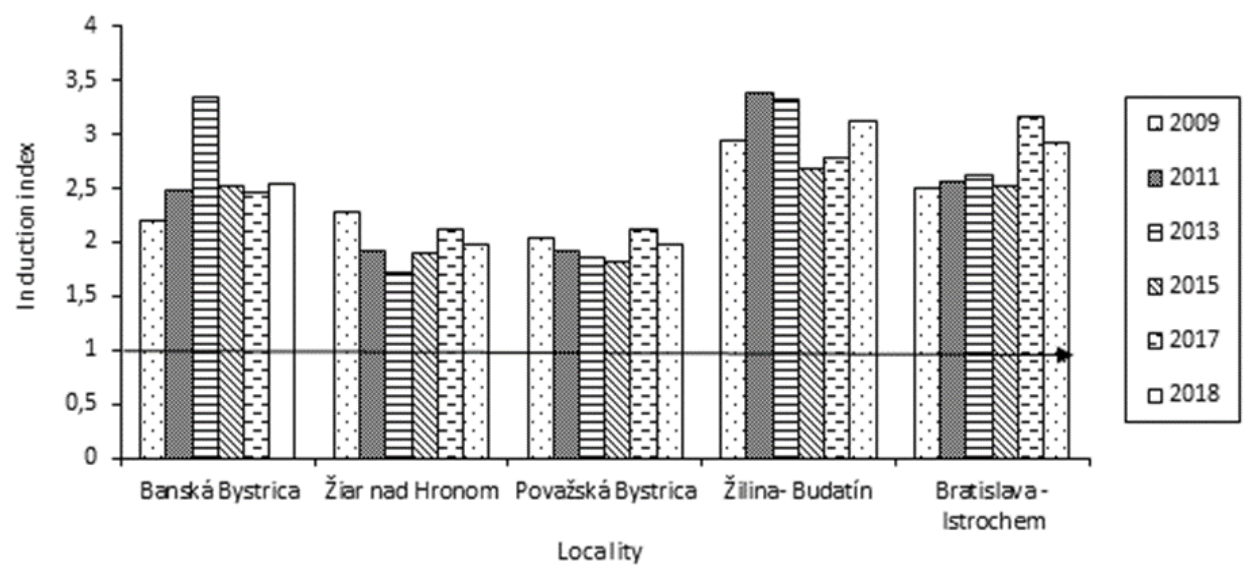

Fig. 4 Induction index of ecogenotoxicity at traffic junctions of Slovakia in years 2009-2018. (The values of pollen abortivity at the monitored sites are expressed by induction indexes, the line with the arrow points to the level of pollen abortivity in the unpolluted reference (control) locality in a protected landscape area of the Záhorie region, approx. $2 \mathrm{~km}$ from the Závod village (GPS: 48 $31^{\prime} 21.18^{\prime \prime} \mathrm{N}$, $\left.17^{\circ} 3^{\prime} 30.23^{\prime \prime} \mathrm{E}\right)$. The detected values of induction indexes more than 1.0 represent significantly increased values of pollen abortivity compared to the reference control site.).

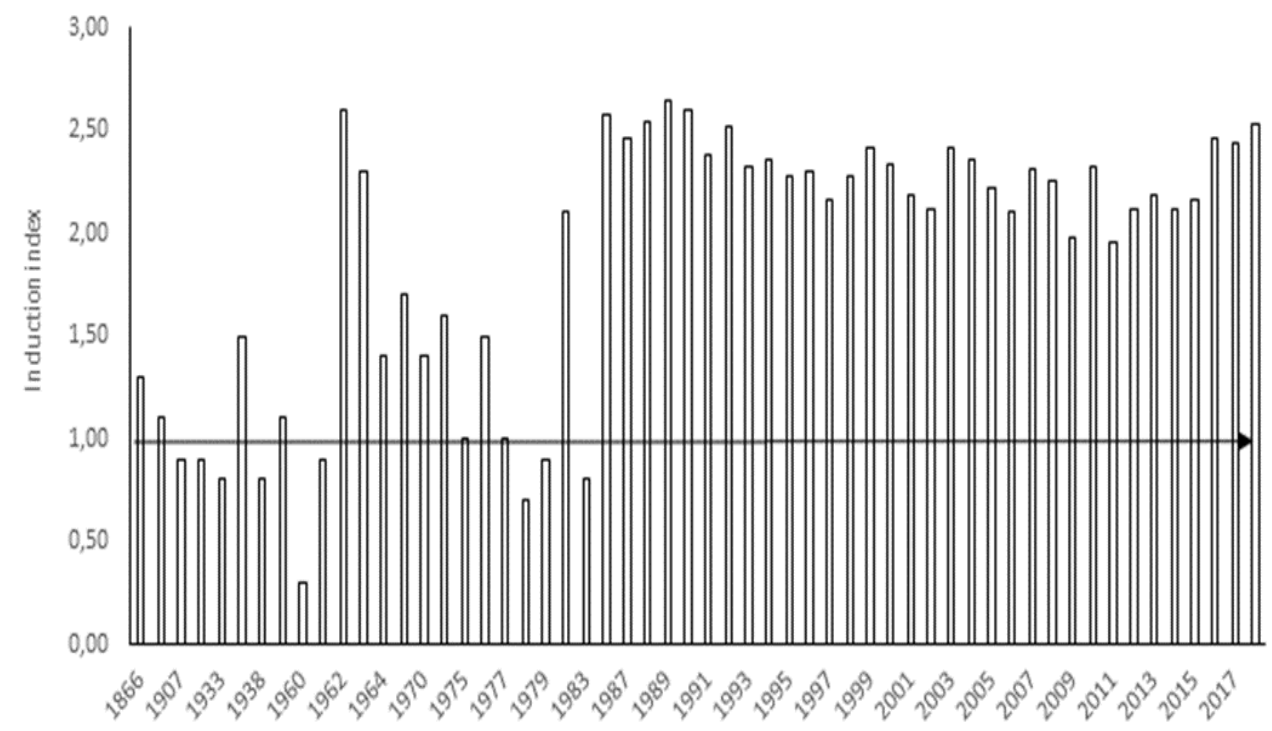

Fig. 5 Induction index of ecogenotoxicity in Bratislava centre in years 1866-2018. The values of pollen abortivity in the Bratislava city centre, expressed by induction indexes. The line with the arrow points to the level of pollen abortivity in the unpolluted reference (control) locality in a protected landscape area of the Záhorie region, approx. $2 \mathrm{~km}$ from the Závod village (GPS: $48^{\circ} 31^{\prime} 21.18^{\prime \prime} \mathrm{N}, 17^{\circ} 3^{\prime} 30.23^{\prime \prime} \mathrm{E}$ ), the detected values of induction indexes more than 1.0 represent significantly increased values of pollen abortivity compared to the reference control site. From the year 1966 to 1987 , induction indexes were calculated as the reference locality average for the last five years, from 2014 to 2018. 
There are also several levels (pollen grains/ microspores, micronuclei in tetrads, and chromosomal aberrations/ mitotic abnormalities in meiosis and mitosis) that we can use for phytotoxic as well as genotoxic impact evaluation of the polluted environment on selected plant species. We could also easily distinguish the physiological (phytotoxic) and genetic (genotoxic) damages.

It can be concluded that pollen abortivity is a highly sensitive, unspecific indicator of environmental quality in study areas. It is found to be appropriate to use this method as a preliminary indicator of assessing an environmental condition in a study area prior to carrying out a more detailed investigation of the presence and impact of specific xenobiotics. In areas without a direct source of pollution, a remote source of pollution can often be identified. The use of pollen abortivity as an indicator also allows determining the overall nonspecific background load on a monitored site.

\section{Acknowledgement}

This study was partially supported by Operational Program: ITMS26240220086

\section{References}

Amphelet G. E. \& Delow G. (1984): Statistical analysis of the micronucleus test. - Mutat. Res. 128: 161-166. doi.org/10.1016/0027-5107(84)90103-9

Aksoy Ö. (2017): Detection of environmental mutagens through plant bioassays. - In: Yousaf Z. (ed.): Plant Ecology - Traditional Approaches to Recent Trends. http://dx.doi.org/10.5772/intechopen.69274

Bhat S. A., Singh J., Singh K. \& Vig A. P. (2017): Genotoxicity monitoring of industrial wastes using plant bioassays and management through vermitechnology: a review. - Agric. Nat. Resour. 51: 325-337. https://doi.org/10.1016/j.anres.2017.11.002

Bhat S. A., Cuic G., Lia F. \& Vig A. P. (2019): Biomonitoring of genotoxicity of industrial wastes using plant bioassays. - Bioresour. Technol. Reports 6: 207-216. https://doi.org/10.1016/j.biteb.2019.03.005

Bianchi J., Espindola E. L. G. \& Marin-Morales MA. (2011): Genotoxicity and mutagenicity of water samples from the Monjolinho River (Brazil) after receiving untreated effluents. Ecotoxicol. Environ. Saf. 74: 826-833. https://doi.org/10.1016/j.ecoenv.2010.11.006

Constantin M. J. \& Owens E. T. (1982): Introduction and perspectives of plant genetic and cytogenetic assays. - Mutat. Res. 99: 1-12. https://doi.org/10.1016/01651110(82)90027-6

De Serres F. J. (1978): Utilization of higher plant systems as monitors of environmental mutagens. - Environ. Health Perspect. 27: 3-6.

Grant W. F. (1982): Chromosome aberration assays in Allium. - Mutat. Res. 99: 273-291. https://doi.org/10.1016/0165-1110(82)90046-X

Grant W. F. \& Zura K. D. (1982): Plants as sensitive in situ detectors atmospheric mutagens. - In: Heddle J. A. (ed.) Mutagenicity - horizon in genetic toxicology. p. 407-434. Academic Press, New York.

Grant W. F., Lee H. G., Logan D. M. \& Salamone M. F. (1992): The use of Tradescantia and Vicia faba bioassays for the in situ detection of mutagens in an aquatic environment. Mutat. Res. 270: 53-64. https://doi.org/10.1016/0027-5107(92)90101-7 
Iqbal M., Abbas M., Nisar J. \& Nazir A. (2019): Bioassays based on higher plants as excellent dosimeters for ecotoxicity monitoring: a review. - Chem. Int. 5: 1-80. https://doi.org/10.5281/zenodo.1475399

Kanaya N., Gill B. S., Grover I. S., Murín A., Osiecka R., Sandhu S. S. \& Andersson H. C. (1994): Vicia faba chromosomal aberration assay. - Mutat. Res. 310: 231-247. https://doi.org/10.1016/0027-5107(94)90116-3

Leme D. M., \& Marin-Morales M. A. (2009): Allium cepa test in environmental monitoring: a review on its application. - Mutat. Res. 682: 71-81. https://doi.org/10.1016/j.mrrev.2009.06.002

Ma T.-H. (1982a): Tradescantia cytogenetic tests (root-tip mitosis, pollen mitosis, pollen mother-cell meiosis). - Mutat. Res. 99: 293-302. https://doi.org/10.1016/01651110(82)90047-1

Ma T.-H. (1982b): Vicia cytogenetics test for environmental mutagens. A report of the U.S. Environment Protection Agency Gene-Tox Programme. - Mutat. Res. 99: 257-271. https://doi.org/10.1016/0165-1110(82)90045-8

Ma T.-H. (1999): The international program on plant bioassays and the report of the followup study after the hands-on workshop in China. - Mutat. Res. 426: 103-106. https://doi.org/10.1016/S0027-5107(99)00049-4

Mazzeo D. E. C. Roberto M. M., Sommaggio L. R. D. \& Marin-Morales M. A. (2018): Bioassays used to assess the efficacy of biodegradation. - In: Toxicity and Biodegradation Testing, p. 215-239. - Humana Press, New York, NY.

Mičieta K. (1989): Cultivated plants as indicators of phytotoxicity and mutagenicity of contaminated environment. - Agriculture (Nitra) 35: 122-131.

Mičieta K. \& Kunová K. (2000): Phytoindication of genotoxic deterioration of polluted environment. - Biológia (Bratislava) 55: 75-79.

Mičieta K. \& Murín G. (1996): Microspore analysis for genotoxicity of a polluted environment. - Environ. Exp. Bot. 36: 21-27.

Mičieta K. \& Murín G. (1997): Wild plant species in practical use for bioindication of polluted environment. - Ekológia (Bratislava) 16: 193-202.

Mičieta K. \& Murín G. (1999): Retrospective biomonitoring: a hundred years of environmental pollution at selected areas in Slovakia. - J Environ. Pathol. Toxicol. 18: 335-338.

Mičieta K. \& Murín G. (2007): Wild plant species in bio-indication of radioactivecontaminated sites around Jaslovské Bohunice nuclear power plant in the Slovak Republic. - J Environ. Radioact. 93: 26-37. https://doi.org/10.1016/j.jenvrad.2006.11.006

Mičieta K. \& Murín G. (2018): "In situ" biomonitoring of polluted environment by wild plant and crop plant species. 224 pp. - Nova Science Publishers, Inc., New York.

Mišík M., Mičieta K., Solenská M., Mišíková K., Pisarčíková H. \& Knasmüller S. (2007): In situ biomonitoring of the genotoxic effects of mixed industrial emissions using the Tradescantia micronucleus and pollen abortion tests with life plants. Demonstration of the efficacy of emission controls in an eastern European city. - Environ. Pollut. 145: 459466. https://doi.org/10.1016/j.envpol.2006.04.026

Murín A. (1984): Simultaneous test for phytotoxic and mutagenic effects of chemically polluted waters and substances of an herbicidal effect. Simultánny test fytotoxických a mutagénnych účinkov chemicky znečistených vôd a látok herbicídnej povahy. - Biológia (Bratislava) 39: 15-24.

Murín A. (1987): Flowers as indicators of mutagenicity and phytotoxicity of pollute environment (in Slovak). - Biológia (Bratislava) 42: 447-456. 
Murín A. (1995): Basic criteria for selection of plant bioindicators from the regional flora for monitoring of an environmental pollution. - Biológia (Bratislava) 50: 37-40.

Paradiž J. \& Lovka M. (1999): Pollen grain bioassay for environmental pollution screening. Phyton - Ann. Rei Bot. 39: 175-182.

Pogányová A., Kerekeš E. \& Mičieta K. (2017): The ecogenotoxic plant biomonitoring of a long-term polluted area in central Slovakia. - Environ. Sci. Pollut. Res. 24: 27376-27383. DOI: 10.1007/s11356-017-0353-z

Pogányová A., Mičieta K. \& Dušička J. (2019): Genotoxic assessment of selected native plants to deferentially exposed urban ecosystems. - Environ. Sci. Pollut. Res. 26: 9064-9055 . https://doi.org/10.1007/s11356-019-04230-1

Salles F. J., de Toledo M. C. B., César A. C. G., Ferreira G. M. \& Barbério A. (2016): Cytotoxic and genotoxic assessment of surface water from Săo Paulo State, Brazil, during the rainy and dry seasons. - Ecotoxicology 25: 633-645. https://doi.org/10.1007/s10646-0161622-1

Solenská M., Mičieta K. \& Mišík M. (2006): Plant bioassay for in situ monitoring of air near an industrial area and a municipal solid waste - Žilina (Slovakia). - Environ. Monit. Assess. 115: 499-508. https://doi.org/10.1007/s10661-006-7240-2

Plewa M. J. (1982): Specific-locus mutation assays in Zea mays: A report of the U.S. environmental protection agency Gene-Tox program - Mutat. Res. 99: 317-337. https://doi.org/10.1016/0165-1110(82)90049-5

Van't Hof J. \& Schairer L. A. (1982): Tradescantia assay system for gaseous mutagens: A report of the U.S. environmental protection agency Gene-Tox program - Mutat. Res. 99: 303315. https://doi.org/10.1016/0165-1110(82)90048-3

Vig B. K. (1982): Soybean [Glycine max L. (Merill)] as a short-term assay for study of environmental mutagens: A report of the U.S. environmental protection agency Gene-Tox program. - Mutat. Res. 99: 339-349. https://doi.org/10.1016/0165-1110(82)90050-1.

Received: October $29^{\text {th }} 2020$

Revised: December 30 th 2020

Accepted: February $20^{\text {th }} 2021$ 